\title{
Levels of and Factors Associated with Birth Registration in the slums of Nairobi
}

\author{
Collins Juma ${ }^{a}$, Donatien Beguy ${ }^{b}$ and Blessing Mberu ${ }^{c}$ \\ African Population and Health Research Center \\ Nairobi, Kenya. \\ cjjuma@gmail.com
}

\begin{abstract}
In this paper, we use data from the Nairobi Cross-sectional Slum Survey 2012 to examine levels and factors associated with birth registration in Nairobi slums. We used descriptive statistics and logistic regression and data of 1719 children aged 0-5 years drawn from 4564 households. We find that children who are at least 3 years, who were born to mothers aged at least 25 years, of Kikuyu/Meru/Embu ethnic groups, who were delivered in health facilities and in the presence of a health professional are more likely to be registered and to have a birth certificate. While education has no net significant effect on birth registration, women with no education, are more likely to get a birth certificate for their children. We recommend interventions by government and civil society to allow birth registration in slum health facilities as well as having outreach programs in informal schools within slums.
\end{abstract}

\section{Introduction}

Birth registration is not only a matter of human rights (United Nations, 1989) but it also serves as an important instrument for a country's development planning. However, the births of nearly one third of the global population of under-five children have never been registered (UNICEF, 2015). In subSaharan Africa, $55 \%$ of children below the age of five are unregistered (Setel et al., 2015); it is the case of $40 \%$ of children in Kenya (Lewandowski, 2015). There is a huge gap between births registration in urban areas (19\% unregistered) compared to rural areas ( $43 \%$ unregistered) while little is known about the proportion of unregistered children in slums (UNICEF, 2003). By missing out on birth registration, it means these children are potentially disenfranchised risking their recognition before the law and related citizen entitlements.

According to a UNICEF report, 60 percent of children aged five years and below do not have a birth certificate in Kenya (UNICEF, 20I5). The higher registration in older children is explained by a requirement for a birth certificate to access education and health care in the country. The report also indicates that many mothers lack knowledge on how to register a child but gender parity in birth registration appears to be the norm in almost all countries (UNICEF, 20I5) . Differences in birth registration levels can be found among children of different religious backgrounds. There is correlation between a family's wealth and birth registration rates, with children from the richest households being more than twice as likely to be registered as children from the poorest households (UNICEF, 20I5). Children of mothers with some level of education are more likely to be registered. In some countries, children living in urban areas are six times more likely to be registered compared to those living in rural areas (UNICEF, 2015). The report however appreciates that this generalization may hide inequalities in some geographic areas such as slum populations. In fact, following extreme poverty and other social and economic deprivations under which the urban poor in slum settlements live, the commonly assumed urban advantage in health and economic outcomes relative to their rural counterparts has been challenged in many parts of the developing world, especially in Kenya (APHRC, 2002; 20I4). Further, various other studies have indicated that slums score poorly compared to other urban and rural areas when it comes to health indicators and service delivery (Kyobutungi et al, 2008 ; Zulu et al, 20I I). Informal schooling and limited access to health facilities has also been reported for slum settlements in Nairobi (APHRC, 20I4). Further, some slum settlements experience frequent fire outbreaks that lead to loss of lives, property and vital documents and in Nairobi the proportion of urban population that reside in slums or live in slum-like conditions is estimated at about $60 \%$ (APHRC, 20I4). 
In this paper, we examine the levels and factors associated with birth registration in Nairobi slums using data from the Nairobi Cross-sectional Slum Survey that the African Population and Health Research Center (APHRC) conducted in 2012 in all Nairobi slums, Kenya.

Being registered confers benefits of legal identity to individuals. It is therefore important to understand why children are not registered, meaning they maybe in many ways invisible, and may be therefore denied their rights to access social protection and inheritance, and may be more vulnerable to exploitation, child labor and human trafficking practices, as well as other opportunities. Consequently, slum children who live in a very challenging environment deserves more attention to help reduce their vulnerabilities.

\section{Background}

In Kenya, there was no attempt at universal birth registration of Africans until 1971 when a legal framework was put in place to allow birth and death registration across the country (Ayieye, 2007). Before independence, birth registration was done in Nairobi and Nyeri on pilot basis to determine whether it would be possible to register Africans. The current law governing registration of births in Kenya is known as the births and deaths registration Act (Pages, 1927). The registration of birth of a new born child typically is facilitated by the local hospital where the child is born or the community healthcare worker present at birth. Currently about $84 \%$ of women reported to deliver in health facilities in Kenya (APHRC, 20I4). Some of the health facilities in slums are not recognized by the government and hence cannot offer birth registration services. If the birth does not take place in a recognized hospital or is not presided over by a community health worker, the parents are expected to report the birth of their child to the nearest government office or government health center to register the child as soon as possible after birth.

Since 2013, civil registration can also be undertaken at "Huduma Centers" that have allowed the government to devolve the access of all government services in select towns across the country (The Standard, 2016). Unlike in the rest of Kenya, the registration process in Nairobi does not involve the provincial administration but the City County medical officer of health who manages the registry of births and deaths (Government of Kenya, $20 / 2$ ). Birth registration that is sought beyond six months after the birth of a child is considered late registration and it attracts not just penalties but more scrutiny. In some cases, those lacking documents for transacting official businesses, such as parents' identification cards, would be referred back to their ancestral homes for a remedy. Such a situation which is common in slums, following high incidences of fire outbreaks that result into loss of vital documents (United Nations Office for Cordination of Humanitarian Affairs, 20I I), underscores the import of this slum-focused analysis.

\section{Data and Methods}

We used data from the second Nairobi Crosssectional Slum Survey (NCSS 20I2), a DHS-type survey that the African Population and Health Research Center (APHRC) conducted in 2012 in all slums of Nairobi city, Kenya. The main objective of the NCSS 2012 was to measure the progress made on key health and wellbeing indicators in urban slums and compare them with those from non-slum Nairobi and other parts of the country. In total, 4564 households were interviewed and a random sample of 4240 women aged 12-49 years were interviewed in the selected households. In this paper, we restricted the analytical sample to 1719 children aged 0-5 years who were recorded in the household roster administered to all households interviewed during the survey. The Kenya Medical Research Institute's ethical review board provided ethical approval for the NCSS 2012.

We consider two dependent variables: birth registration (yes if registered and no if not) and possession of birth certificate after registration (yes if birth certificate issued and no if not) were collected in a household listing module of the survey. Independent variables include: child's age, gender, place of birth, mother's age, religion, ethnicity, marital status and education of the child's mother as well as the household wealth index that were collected both in the household and women's module.

We use descriptive statistics and multivariate logistic regression to look at levels of and factors associated with birth registration in Nairobi slums in 2012. Stata 13.I was used for all analyses (Stata, 20/3). To account for potential lack of independence for children living in the same household, we used robust estimates for the standard errors.

\section{Descriptive Findings}

Overall, $72 \%$ of children were registered at birth but only $30 \%$ had a birth certificate (Figure I). Data from the KDHS 2014 indicate higher figures for Nairobi County as a whole; $80 \%$ of under- 5 children had their births registered and $43 \%$ had a birth certificate in 2014 . 
Figure I: Birth Registration in Nairobi Slums

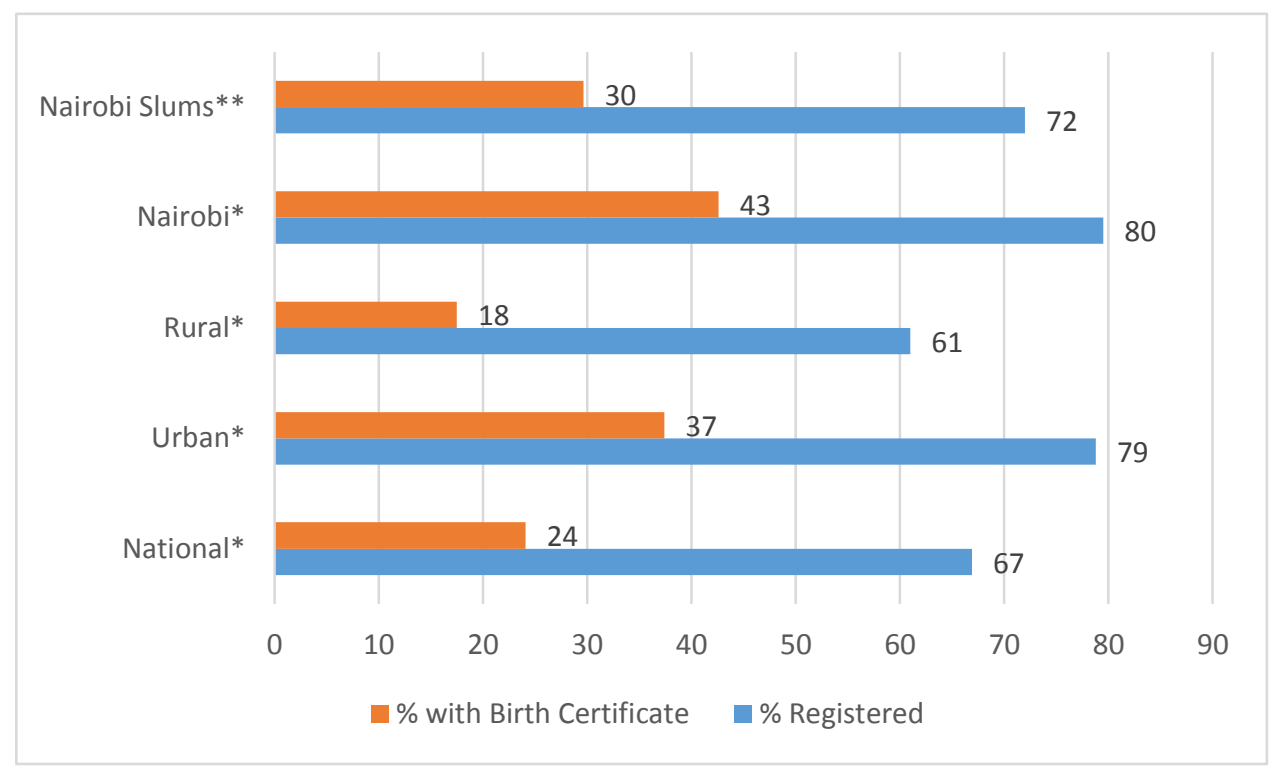

Source: *2014 Kenya Demographic and Health Survey (KDHS) and **APHRC NCSS 2012

We also present in Table I the distribution of birth registration by socio-demographic characteristics of the child and the mother. Data show that higher percentages of children are registered at age 2 and 3 . The birth certificate is sought more as the child gets older and it peaks as the child turns 3. Consistent with literature, there is gender parity as far as birth registration and getting certificate is concerned. As expected, children born in Nairobi have a marginal advantage in terms of registration (73\% vs $69 \%)$ and in certification compared to those born elsewhere in Kenya ( $31 \%$ vs $26 \%)$. Children of older mothers are more likely to be registered compared to those of young mothers. Children born to Protestant mothers are also more likely to be registered compared to those born to mothers from other religious groups. Ethnicity is another important factor that has cultural underpinnings that could affect birth registration. Mothers from Kikuyu ethnic groups (including Meru and Embu) and Kisii are most likely to register their children's birth $(77 \%$ and $78 \%$ respectively as compared to $71 \%$ for Luhyas; $70 \%$ for Kambas; $67 \%$ for Luo mothers).

Children whose mother have college and university education have an advantage over those who have secondary and primary education. Compared to mothers who have no education at all, mothers with primary and secondary education only have a marginal advantage. Kibera holds an advantage over all other divisions in Nairobi but for Dagoretti, which is in the peri-urban. Children in richer households were more registered compared to those from poor households $(78 \%$ vs. $61 \%)$. They were also more likely to get a birth certificate after registration (38\% vs $18 \%)$. As expected, children delivered in health facilities $(74 \%)$ are more likely to be registered compared to those whose birth occurred at home $(55 \%)$ or elsewhere $(59 \%)$.

Table I. Percentage of children whose birth was registered and with a birth certificate in Nairobi slums, NCSS 2012.

\begin{tabular}{|l|l|l|l|l|}
\hline Socio-demographics & \% Registered & $\mathbf{N}$ & $\begin{array}{l}\text { Among Registered } \\
\text { \% with certificate }\end{array}$ & $\mathbf{N}$ \\
\hline $\begin{array}{l}\text { Child's age*: } \\
\text { <I year }\end{array}$ & 71.4 & 430 & 19.2 & 307 \\
I & 71.2 & 372 & 26.4 & 265 \\
2 & 72.6 & 398 & 30.8 & 289 \\
3 & 72.3 & 364 & 35.7 & 263 \\
4 & 69.7 & 313 & 35.3 & 218 \\
5 & 68.1 & 257 & 34.9 & 175 \\
\hline Child sex: & & 1066 & 28.8 & 764 \\
Male & 71.7 & 1068 & 30.5 & 753 \\
Female & 70.5 & & & \\
\hline
\end{tabular}


African Population Studies Vol. 30, No. 2, (Supp.),2016

\begin{tabular}{|c|c|c|c|c|}
\hline $\begin{array}{l}\text { Child's place of Birth: } \\
\text { Other Kenya } \\
\text { Nairobi }\end{array}$ & $\begin{array}{l}67.4 \\
71.9\end{array}$ & $\begin{array}{l}377 \\
1757\end{array}$ & $\begin{array}{l}27.2 \\
30.2\end{array}$ & $\begin{array}{l}254 \\
1263\end{array}$ \\
\hline $\begin{array}{l}\text { Mother's age*: } \\
\text { Less than } 25 \text { years } \\
25-29 \text { years } \\
30-34 \text { years } \\
35+\text { years }\end{array}$ & $\begin{array}{l}67.7 \\
72.9 \\
71.7 \\
75.2 \\
\end{array}$ & $\begin{array}{l}761 \\
816 \\
343 \\
214\end{array}$ & $\begin{array}{l}20.6 \\
31.8 \\
37.0 \\
39.8 \\
\end{array}$ & $\begin{array}{l}515 \\
595 \\
286 \\
161\end{array}$ \\
\hline $\begin{array}{l}\text { Mother's religion: } \\
\text { Catholic } \\
\text { Protestant } \\
\text { Pentecostal/Charismatic } \\
\text { Other Christian } \\
\text { Other }\end{array}$ & $\begin{array}{l}71.9 \\
72.0 \\
70.7 \\
68.5 \\
70.5\end{array}$ & $\begin{array}{l}545 \\
626 \\
628 \\
238 \\
95\end{array}$ & $\begin{array}{l}31.6 \\
26.2 \\
32.2 \\
28.2 \\
28.4\end{array}$ & $\begin{array}{l}392 \\
451 \\
444 \\
163 \\
67\end{array}$ \\
\hline $\begin{array}{l}\text { Mother's ethnicity: } \\
\text { Kamba } \\
\text { Kikuyu/Meru/Embu } \\
\text { Kisii } \\
\text { Luhya } \\
\text { Luo } \\
\text { Other }\end{array}$ & $\begin{array}{l}70.2 \\
76.7 \\
77.5 \\
70.8 \\
66.5 \\
62.5\end{array}$ & $\begin{array}{l}439 \\
463 \\
173 \\
530 \\
421 \\
104\end{array}$ & $\begin{array}{l}28.9 \\
34.7 \\
35.1 \\
27.2 \\
23.6 \\
35.4\end{array}$ & $\begin{array}{l}308 \\
355 \\
134 \\
375 \\
280 \\
65\end{array}$ \\
\hline $\begin{array}{l}\text { Mother's Marital status: } \\
\text { Never married } \\
\text { Currently married } \\
\text { Formerly married }\end{array}$ & $\begin{array}{l}72.6 \\
71.3 \\
67.4 \\
\end{array}$ & $\begin{array}{l}168 \\
1820 \\
135\end{array}$ & $\begin{array}{l}23.8 \\
30.3 \\
27.5\end{array}$ & $\begin{array}{l}122 \\
1297 \\
91\end{array}$ \\
\hline $\begin{array}{l}\text { Mother's education*: } \\
\text { No education } \\
\text { Primary } \\
\text { Secondary } \\
\text { College/University }\end{array}$ & $\begin{array}{l}71.4 \\
66.3 \\
75.4 \\
84.9\end{array}$ & $\begin{array}{l}35 \\
1128 \\
816 \\
152\end{array}$ & $\begin{array}{l}47.1 \\
23.6 \\
35.2 \\
42.6\end{array}$ & $\begin{array}{l}25 \\
748 \\
615 \\
129\end{array}$ \\
\hline $\begin{array}{l}\text { Location in Nairobi*: } \\
\text { Dagoretti } \\
\text { Kibera } \\
\text { Embakasi } \\
\text { Makadara } \\
\text { Central } \\
\text { Kasarani } \\
\text { Pumwani } \\
\text { Westlands }\end{array}$ & $\begin{array}{l}79.4 \\
79.0 \\
71.8 \\
71.2 \\
53.9 \\
63.0 \\
61.6 \\
71.2 \\
\end{array}$ & $\begin{array}{l}334 \\
309 \\
606 \\
170 \\
154 \\
278 \\
99 \\
184\end{array}$ & $\begin{array}{l}33.7 \\
27.5 \\
25.1 \\
54.6 \\
28.9 \\
17.1 \\
31.2 \\
34.4 \\
\end{array}$ & $\begin{array}{l}267 \\
244 \\
435 \\
121 \\
83 \\
175 \\
61 \\
131\end{array}$ \\
\hline $\begin{array}{l}\text { Wealth Tertile*: } \\
\text { Lowest } \\
\text { Middle } \\
\text { Highest }\end{array}$ & $\begin{array}{l}61.4 \\
69.0 \\
78.4\end{array}$ & $\begin{array}{l}523 \\
710 \\
901\end{array}$ & $\begin{array}{l}18.1 \\
25.7 \\
37.7 \\
\end{array}$ & $\begin{array}{l}321 \\
490 \\
706 \\
\end{array}$ \\
\hline $\begin{array}{l}\text { Delivery Place*: } \\
\text { Health facility } \\
\text { Home } \\
\text { Other }\end{array}$ & $\begin{array}{l}74.2 \\
55.4 \\
59.4\end{array}$ & $\begin{array}{l}1777 \\
325 \\
32 \\
\end{array}$ & $\begin{array}{l}30.1 \\
27.2 \\
26.3 \\
\end{array}$ & $\begin{array}{l}1318 \\
180 \\
19\end{array}$ \\
\hline $\begin{array}{l}\text { Delivery provider*: } \\
\text { Doctor/Nurse/Midwife } \\
\text { Traditional Birth Attendant/ } \\
\text { Community Health Worker } \\
\text { Relative/ Other Provider } \\
\text { None }\end{array}$ & $\begin{array}{l}73.4 \\
58.3 \\
46.9 \\
67.3\end{array}$ & $\begin{array}{l}1791 \\
175 \\
64 \\
104\end{array}$ & $\begin{array}{l}30.3 \\
24.5 \\
16.7 \\
30.0\end{array}$ & $\begin{array}{l}1315 \\
102 \\
30 \\
70\end{array}$ \\
\hline Total & 71.7 & 1719 & 30.3 & 1517 \\
\hline
\end{tabular}

* Significant at $5 \%$ level. 
Findings from multivariate analysis

Results from multivariate analysis for birth registration and having a birth certificate after registration for children aged 0-5 years are presented in Table 2. Although child's age is not significantly associated with birth registration, data show that children 3 years and beyond are twice as likely to have a birth certificate after registration compared to those aged less than a year, with the difference being significant at the 5 percent level. In terms of ethnicity, children born to Luo mothers are 32 percent less likely to be registered compared to those born to Kikuyu/Meru/Embu mothers. Children from other smaller tribes are also less likely to be registered compared to those from the dominant tribe in Kenya. However, among those that are registered in the small tribes including Maasai, Nubians, Somali, Mijikenda, Swahili and others are more likely to get a birth certificate underscoring how identification is important to minority groups. Older mothers (aged at least 25) are significantly more likely than those aged less than 25 to register their child's birth and get a birth certificate.

Table 2: Factors associated with birth registration and having a birth certificate after registration for children aged $0-5$ years (Logistic regression).

\begin{tabular}{|c|c|c|}
\hline Socio-demographics & $\begin{array}{l}\text { Logistic regression model } \\
\text { for being registered }\end{array}$ & $\begin{array}{l}\text { Logistic regression model for } \\
\text { having a birth certificate }\end{array}$ \\
\hline $\begin{array}{l}\text { Age of child (years) } \\
<\text { I year } \\
1 \\
2 \\
3 \\
4 \\
5\end{array}$ & $\begin{array}{l}\text { Ref. } \\
\text { I.00 }(0.72-1.38) \\
\text { I.10(0.80- } 1.53) \\
\text { I.0। }(0.72-1.41) \\
0.88(0.62-1.24) \\
0.74(0.51-1.07)\end{array}$ & $\begin{array}{l}\text { Ref. } \\
\text { I.48* }(0.97-2.26) \\
\text { I.64** }(1.09-2.48) \\
2.23 * * *(1.47-3.39) \\
2.01 * * *(1.30-3.09) \\
\text { I.76** }(1.10-2.8 I)\end{array}$ \\
\hline $\begin{array}{l}\text { Child sex } \\
\text { Male } \\
\text { Female }\end{array}$ & $\begin{array}{l}\text { Ref. } \\
0.94(0.77-1.15)\end{array}$ & $\begin{array}{l}\text { Ref. } \\
\text { I.II }(0.87-1.4 \mathrm{I})\end{array}$ \\
\hline $\begin{array}{l}\text { Child's birth place } \\
\text { Outside Nairobi } \\
\text { Nairobi }\end{array}$ & $\begin{array}{l}\text { Ref. } \\
0.99(0.75-1.29)\end{array}$ & $\begin{array}{l}\text { Ref. } \\
\text { I.15 }(0.81-1.64)\end{array}$ \\
\hline $\begin{array}{l}\text { Mothers ethnicity } \\
\text { Kikuyu/Meru/Embu } \\
\text { Kamba } \\
\text { Kisii } \\
\text { Luhya } \\
\text { Luo } \\
\text { Other }\end{array}$ & $\begin{array}{l}\text { Ref } \\
0.83(0.60-1.14) \\
1.00(0.64-1.56) \\
0.77(0.57-1.06) \\
0.68 * *(0.49-0.94) \\
0.40 * * *(0.24-0.68)\end{array}$ & $\begin{array}{l}\text { Ref. } \\
0.87(0.60-1.25) \\
0.98(0.61-1.59) \\
0.75(0.53-1.07) \\
0.71 *(0.48-1.05) \\
1.26(0.63-2.55)\end{array}$ \\
\hline $\begin{array}{l}\text { Mother's religion } \\
\text { Catholic } \\
\text { Protestant } \\
\text { Pentecostal/charismatic } \\
\text { Other Christian }\end{array}$ & $\begin{array}{l}\text { Ref. } \\
0.94(0.71-1.24) \\
0.97(0.74-1.27) \\
0.94(0.66-1.34)\end{array}$ & $\begin{array}{l}\text { Ref. } \\
0.68(0.49-0.96) \\
1.09(0.80-1.50) \\
\text { I.04 }(0.68-1.61)\end{array}$ \\
\hline
\end{tabular}

http://aps.journals.ac.za
Mother's level of education attainment does not have significant influence on birth registration in slums. However, it is significantly associated with having a birth certificate once registered, with women with no education twice as likely to get birth certificate for their children upon registration compared to those with college or university education. The location in Nairobi from which a child's household resides has a significant influence on birth registration. Compared to Kibera which is one of the largest slum settlements with a big presence of civil society organizations, all other slum settlements are less likely to register their children's birth. However, when it comes to having a birth certificate, most children in Kibera are not usually given birth certificates and they only hold an advantage over Kasarani and Embakasi. Children from the highest wealth tertile are more than twice as likely to not only be registered but also be awarded a birth certificate. Children born in health facilities and whose delivery was assisted by a health professional are more likely to be registered and given certificates. 


\begin{tabular}{|c|c|c|}
\hline Other & $1.50(0.82-2.72)$ & $0.58(0.27-1.22)$ \\
\hline $\begin{array}{l}\text { Mother's age } \\
\text { Less than 25yrs } \\
25-29 y r s \\
30-34 y r s \\
35+\end{array}$ & $\begin{array}{l}\text { Ref. } \\
\text { I.I7 (0.92 - I.49) } \\
\text { I.04 }(0.75-1.42) \\
\text { I. } .42 *(0.98-2.07)\end{array}$ & $\begin{array}{l}\text { Ref. } \\
\text { I.45**(I.07- I.98) } \\
1.77^{* * *}(1.21-2.58) \\
1.93^{* * *}(1.26-2.95)\end{array}$ \\
\hline $\begin{array}{l}\text { Mother's marital status } \\
\text { Never Married } \\
\text { Currently married } \\
\text { Formerly married }\end{array}$ & $\begin{array}{l}\text { Ref. } \\
0.80(0.54-1.17) \\
0.81(0.47-1.38)\end{array}$ & $\begin{array}{l}\text { Ref. } \\
\text { I.40 }(0.88-2.21) \\
\text { I.16 }(0.60-2.23)\end{array}$ \\
\hline $\begin{array}{l}\text { Mother's education } \\
\text { No education } \\
\text { Primary } \\
\text { Secondary } \\
\text { College/University } \\
\end{array}$ & $\begin{array}{l}\text { Ref. } \\
1.13(0.25-1.35) \\
0.77(0.33-1.81) \\
1.11(0.43-2.89)\end{array}$ & $\begin{array}{l}\text { Ref. } \\
0.23^{* * *}(0.10-0.55) \\
0.37^{* *}(0.15-0.91) \\
0.50(0.20-1.28)\end{array}$ \\
\hline $\begin{array}{l}\text { Location in Nairobi } \\
\text { Kibera } \\
\text { Dagoretti } \\
\text { Embakasi } \\
\text { Makadara } \\
\text { Central } \\
\text { Kasarani } \\
\text { Pumwani } \\
\text { Westlands }\end{array}$ & $\begin{array}{l}\text { Ref. } \\
\text { I.02 }(0.67-1.54) \\
0.59 * * *(0.4 \mid-0.84) \\
0.5 \text { I*** }(0.32-0.80) \\
0.30^{* * * *}(0.19-0.46) \\
0.44 * * *(0.30-0.65) \\
0.35 * * *(0.21-0.58) \\
0.56 * *(0.36-0.87) \\
\end{array}$ & $\begin{array}{l}\text { Ref. } \\
\text { I.19(0.78-I.80) } \\
0.65 * *(0.44-0.97) \\
2.70 * * *(I .65-4.40) \\
0.92(0.51-1.65) \\
0.54 *(0.33-0.90) \\
1.06(0.56-2.02) \\
0.98(0.59-1.62)\end{array}$ \\
\hline $\begin{array}{l}\text { Wealth tertile } \\
\text { Lowest } \\
\text { Middle } \\
\text { Highest }\end{array}$ & $\begin{array}{l}\text { Ref. } \\
\text { I.38** }(1.07-1.77) \\
2.011 * * *(1.62-2.74) \\
\end{array}$ & $\begin{array}{l}\text { Ref. } \\
\text { I.5I** }(1.04-2.19) \\
2.46^{* * * *}(1.73-3.51)\end{array}$ \\
\hline $\begin{array}{l}\text { Delivery Place } \\
\text { Health facility } \\
\text { Home } \\
\text { Other }\end{array}$ & $\begin{array}{l}\text { Ref. } \\
0.62 * *(0.40-0.96) \\
0.67(0.28-1.59) \\
\end{array}$ & $\begin{array}{l}\text { Ref. } \\
\text { I.54 }(0.81-2.95) \\
0.80(0.27-2.39) \\
\end{array}$ \\
\hline $\begin{array}{l}\text { Delivery provider } \\
\text { Doctor/Nurse/Midwife } \\
\text { TBA/CHW } \\
\text { Relative/Other Provider } \\
\text { None }\end{array}$ & $\begin{array}{l}\text { Ref. } \\
0.92(0.54-1.55) \\
0.60(0.31-1.17) \\
1.10(0.65-1.88)\end{array}$ & $\begin{array}{l}\text { Ref. } \\
0.78(0.37-1.65) \\
0.41(0.13-1.30) \\
0.95(0.48-1.89)\end{array}$ \\
\hline $\begin{array}{l}\text { Wald Chi-square } \\
\mathrm{N}\end{array}$ & $\begin{array}{l}159.4 \\
2116\end{array}$ & $\begin{array}{l}162.8 \\
1,510\end{array}$ \\
\hline
\end{tabular}

*** $p<0.0$ I, ** $p<0.05,{ }^{*} p<0.1$.

\section{Discussion and Conclusion}

The main objective of this paper was to examine levels and factors associated with birth registration in Nairobi slums. In total, $72 \%$ of children aged 0-5 years were registered at birth, and $30 \%$ had a birth certificate. The recent KDHS 2014 suggest that in Nairobi County, $80 \%$ of under-5 children had their births registered and $43 \%$ had a birth certificate (Kenya National Bureau of Statistics, 20l4). This suggests that slum children are more likely to remain invisible as compared to other segments of urban populations, rendering them unseen, uncountable and disadvantaged in terms of access to social basic services. Findings indicate that child's age is a significant factor for birth certification with a 3-yearold being twice as likely to have a birth certificate as a one-year-old. Most of the registration is done at birth primarily because most births are in hospitals (APHRC, 20I4). In Kenya, most children are admitted to pre-unit school at age three. The Ministry of Education gazette new requirements is for children to have a birth certificate before being admitted in schools. Although this has not been strictly enforced, it acts as a reminder for parents to get birth certificates for their children. However, it is also a requirement for all those planning to sit national exams at primary and secondary level to have a birth certificate (KNEC, 20/2). However, 
attempts to incentivize birth registration through making a birth certificate mandatory for access to services (such as entry to school exams) creates additional barriers to access to services for unregistered children, who are often already vulnerable (Lewandowski, 20I5). Most of the children in slums attend informal schools (Oketch et al, 20I0), which may waive the requirement for birth certificates in order to have more numbers. Eventually, these children end up as disadvantaged adults when they fail to transit to formal secondary schools. Children born in Nairobi slums have no advantage compared to children born outside Nairobi. Although Nairobi has better health facilities for delivery, higher numbers of hospital deliveries reported may be in facilities that are not recognized by the government for birth registration. However, proximity to administrative offices may explain the slight advantage when it comes to birth certification. Older mothers are more likely to register and get a birth certificate for their children. This may be explained by the fact that older women have more information based on their previous births.

Mothers' level of education does not affect birth registration. It was weakly significant only in obtaining a birth certificate. This is contrary to literature that was discussed in the introduction (Lewandowski, 2015). The overall weakness of education finds support in evidence from a previous nationwide study, which showed diminished independent role of education as a pathway out of poverty in Kenya due to relatively few formal job opportunities (Kristjanson et al. 2010). However, in the context of high unemployment, living in the slums with higher education may be an indicator that the education of the respondent has not successfully been translated into formal employment and economic advantage. Administrative and informal fees can also pose a prohibitive financial barrier to participation, so is complex procedure or inconsistent information in the public domain on registration (Brewer et al, 20I5). In the slums, informal knowledge may play a more important role of passing information compared to mainstream media where more educated women may be more dependent on. Women with no education may be more adapted to slum life and be more involved in agency compared to those who have education and hope to leave the slum as soon as the opportunity arises. For women who do not deliver in recognized hospital or do so at home, the process of getting the birth of their child registered is through the local administration. This process requires a lot of patience.

In sum, the enhancing or constraining factors to birth registration are place of birth of child, child's age, and ethnicity of the mother. Bigger communities that may have better education tend to have a greater agency and thus can easily access civil authorities and register their children. Because slums have vulnerable communities with little access to facilities, there may be need for birth registration to be done in the available delivery facilities within these slums even though most of the facilities are informal. The alternative will be to strengthen the referral system by traditional birth attendants and community health workers that are active in these slum communities. This will also narrow the gap between those who register and those who eventually get birth certificates by removing distance and other barriers.

\section{References}

APHRC. (20I4). Population and Health Dynamics in Nairobi's Informal Settlements: Report of the Nairobi Cross-sectional Slums Survey (NCSS) 2012. Nairobi: African Population and Health Research Center. ISBN 9-789966-I 75427.

Ayieye, J. E. (2007, June 15). Birth registration in perspective. Nairobi, Kenya.

Brewer M., Menzies N., and Schott J., "Making Identification Systems Work for the Bottom 40\%," Just Dev., no. 8, 2015.

Government of Kenya. (2012). Laws of Kenya: Births and Deaths Registration Act . Nairobi: Government Printer.

Kenya Law Review. (201I, January 01). Births and deaths registration. Retrieved August 06, 2015, from Kenya Law: http://www.kenyalaw.org:8I8I/exist/kenyalex/act viewbyid.xql?id=KE/LEG/EN/AR/B/CHAPTER\%2 0149

Kenya National Bureau of Statistics. (20/4). Demographic and Health Survey. Nairobi: Government Printer.

KNEC, "Instructions for registration of National exams." Kenya National Exams Council, Nairobi, 2012.

Kristjanson, P. N. Mango, A. Krishna, M. Radeny and $\mathrm{N}$. Johnson (20I0) Understanding poverty dynamics in Kenya, Journal of International Development, 22, 978-996.

Kyobutungi C., Ziraba A., Ezeh A., and Yé Y., "The burden of disease profile of residents of Nairobi's slums: Results from a Demographic Surveillance System," Popul. Health Metr., vol. 6, no. I, p. I, 2008.

Lewandowski C. M., "Birth registration and childrens rights: a complex story," Eff. Br. mindfulness Interv. acute pain Exp. An Exam. Individ. Differ., vol. I, 2015.

Oketch M., Mutisya M., Ngware M., and Ezeh A. C., "Why are there proportionately more poor pupils 
enrolled in non-state schools in urban Kenya in spite of FPE policy?," Int. J. Educ. Dev., vol. 30, no. I, pp. 23-32, 2010.

Pages C. A., "Births and Deaths Registration Act, 1926.," Br. Med. J., vol. I, no. 3467, pp. III8III9, 1927.

Setel P. W., Macfarlane S. B., Szreter S., Mikkelsen L., Jha P., Stout S., and Abouzahr C., "Who

Counts? I A scandal of invisibility: making everyone count by counting," vol. 370, pp. 2003-2006, 2007.

StataCorp, Stata Statistical software, Release 13., vol. Statistica. College Station, TX: StataCorp LP, 2013.

The Standard. (2016, January 18). There will be Huduma centres in all the 47 counties. Nairobi, Kenya.

Unicef, "UNICEF fact sheet: Birth registration." 2003.

Unicef. (20I5, May I5). Birth registration. Retrieved July 17, 2015, from data.unicef.org: http://data.unicef.org/child-protection/birthregistration

United Nations, "Convention on the Rights of the Child," New York. 1989.

United Nations. (1990, September 2). Convention on the Rights of the Child. Retrieved 8 4, 20I5, from ohchr.org:

http://www.ohchr.org/en/professionalinterest/pag es/crc.aspx

United Nations Office for Cordination of Humanitarian Affairs. (201I, March 3). Kenya Urban Disasters: Fire. Nairobi, Kenya.

Zulu E. M., Beguy D., Ezeh A. C., Bocquier P., Madise N. J., Cleland J., and Falkingham J., "Overview of migration, poverty and health dynamics in Nairobi City's slum settlements," J. Urban Heal., vol. 88, no. SUPPL. 2, pp. 185-199, $201 \mathrm{I}$. 